\title{
Errata for Part I
}

this Archive 20 (2) (1979), 97-188.

Page 114, line 21:

For 1900: 224) read (1900:224)

Page 129, line 1 from bottom:

For Halstead read Halsted

Page 138, diagram:

$\begin{array}{llll}\text { For } & a^{\mathrm{I}} & \text { read } & a^{\prime} \\ \text { For } & a^{\mathrm{II}} & \text { read } & a^{\prime \prime} \\ \text { For } & a^{\mathrm{III}} & \text { read } & a^{\prime \prime \prime} \\ \text { For } & b^{\mathrm{I}} & \text { read } & b^{\prime} \\ \text { For } & b^{\mathrm{II}} & \text { read } & b^{\prime \prime} \\ \text { For } & b^{\mathrm{II}} & \text { read } & b^{\prime \prime \prime} \\ \text { For } & d^{\mathrm{I}} & \text { read } & d^{\prime} \\ \text { For } & d^{\mathrm{II}} & \text { read } & d^{\prime \prime} \\ \text { For } & d^{\mathrm{II}} & \text { read } & d^{\prime \prime \prime}\end{array}$

Page 144, lines 24-25:

For ( read (

Page 149, line 1 from bottom:

For in 1889 read of 1899 is

Page 172, line 24:

For exterior measure read measure (in the sense of BOREL and LEBESGUE)

Page 176, line 4:

For y-axis read $y$-axis

Page 182, line 16:

for Halstead read Halsted 